\title{
The Arab Spring and Democratization; Why is Syria Different?
}

\author{
Ahmad Sahide* \\ ahmadsahidie@gmail.com
}

\begin{abstract}
The Arab Spring is the momentum of the rise of the political power in the Middle East. It brought hope to have political power, namely democracy. So the people power demanded democracy for their life. Syria is one of the states impacted by the Arab Spring where the regime is shaken by this political turbulence.In this paper, it's said that the democratization in Syria failed before the successfulness of the people in overthrowing Assad's regime. Syria is different from Tunisia which succeeded in consolidating democracy. Syria is also different from Egypt which succeeded in consolidating democracy and passing background condition, even though failed in the prefatory fase (second step of the democratization). Here, it's found that one of the factors why the democratization in Syria failed is the foreign intervention. Two biggest states are contesting in having influence and control in Syria, those are United States of America and Russia.
\end{abstract}

Keywords: Arab Spring, Democracy, failure, foreign intervention, Syria,

\begin{abstract}
Abstrak
Arab Spring merupakan momentum kebangkitan kekuatan politik di Timur Tengah. Momentum tersebut membawa harapan berupa munculnya demokrasi. Dengan demikian, selama berlangsungnya Arab Spring, rakyat terus berupaya mendesak pemerintah agar demokrasi diterapkan. Suriah merupakan salah satu negara yang terkena dampak Arab Spring. Tulisan ini menyebutkan bahwa proses demokratisasi di Suriah telah gagal sebelum jatuhnya rezim Assad. Suriah berbeda dengan Tunisia yang berhasil dalam konsolidasi demokrasi. Suriah juga berbeda dengan Mesir yang berhasil dalam konsolidasi demokrasi dan melewati kondisi latar belakang, meskipun gagal dalam fase Pendahuluan (langkah kedua dari demokratisasi). Dari sini, telah ditemukan bahwa salah satu faktor kegagalan demokratisasi di Suriah ialah adanya intervensi asing. Terdapat dua terbesar negara besar yang bertarung dalam mendapatkan pengaruh dan kontrol di Suriah, yaitu Amerika Serikat dan Rusia.

Kata Kunci:Arab Spring, Demokrasi, Intervensi Asing, Kegagalan, Suriah.
\end{abstract}

\section{Preface}

The Arab States are known as the states which sustain authoritarian political culture. It could be proven by the appearing of the leaders who had an absolute power (far from the critic and people control) and the leaders held the power for a long time. However, the political elites who had been in power for a long time were faced with the rise of the people power shaking their positions. Some leaders from the Arab states lost their positions, such as Zein al-Abidin Ben Ali in

*Korespondensi: Magister Ilmu Hubungan Internasional. Universitas Muhammadiyah Yogyakarta, Jl. Lingkar Selatan Tamantirto Bantul, Daerah Istimewa Yogyakarta, 0274-387656, Email: ahmadsahidie@gmail.com 
Tunisia and Hosni Mubarak in Egypt. Some other leaders are facing the same threat, losing a power. The great political turbulence in that region is known as The Arab Spring.

The Arab Spring is the political term which began to be popular in international politics, mainly in the Arab states, since the beginning of January 2011. The term shows the fall of some Arab leaders, started from Ben Ali and followed by the fall of Mubarak in Egypt. Afterwards, it continued in Libya to end the dictatorship era of Moammar Khadafy which had been lasting for about 40 years, continued in Yemen, Bahrain, and Syria which has been lasting for about six years.

Arab people call this important political event with the name al-Tsaurat al-Arabiyyah which is the revolution that will change the political order toward the ideal society and nation after being ordered by the authoritarian system, with the unlimited power, by controlling freedom of the society and creating imbalances between the elites (leaders), living in the luxury, and the poor people. The West calls this event with The Arab Spring that is the turning point of the development of the democracy in the Arab states (Burdah, 2014: 21).

Therefore, this political event became the beginning of stopping the political system in the Arab states which are not transparent and also the unlimited power from the leaders (presidents). This event became the beginning to build the more transparent system and life order, also to give limitation of the leader powers by giving chance and freedom for the people to participate in the political sector, either to choose or to be chosen, or to participate in controlling the running of the government. It aims to create prosperity for the people, to increase the life standard of the society, to omit the asymmetry between elite and people in general, to decrease jobless and poverty, to guarantee sameness of the political right for every society.

In order word, it is the democracy dreamed by the Arab people, either before or after the Arab Spring happened in 2011. Thus, after the turbulence of the Arab Spring, democracy becomes an interesting topic of talking to see the future of the Arab world. People began to be brave of giving their voices about democracy. The political event of 2011 became the event to open the chance for the society to be brave to ask about his political aspiration, mainly the aspiration for the democratic life. 
It can be said that the Arab Spring, since 2011, was followed by some movements of protesting the political stability in the Middle East, was the momentum becoming the trigger factor of the reborn of hope towards the democracy in Arab states. It became the beginning of great change in the Middle East which was the beginning of democratization signed by fall of some authoritarian leaders.

However, Hwang, noting from Jack Snyder, said that it was needed the reliably democratic political institutions as the previous one of the democratic transition to prevent the elite of exploiting exclusionary nationalism to spread instability and conflict (Hwang: 6). In the aspect of forming the democratic institutions; such as sharing power, limited and controlled power, democratization has challenge. This was same as what was said by Larbi Sadiki, from Australian National University, in which in the democratization, the challenge was how to make system (law) which can sustain, neutral, and gives guarantee of the same chance for every people (Sadiki, 2014).

\section{Theory}

This research is done to respond the Arab Spring happening since the early 2011. The political turbulence is viewed by many scholars and analysts as the beginning of the democratization era in those states. Even though some analysts also worry after its running for some years which hasn't given positive developments. Thus, the focus of this research is to study the challenge of the democratization in the Arab states, mainly in Tunisia, Egypt, and Syria after the Arab Spring happed. Theory used by the researcher to study this case is the theory of democracy. Meanwhile, the writer utilizes theory of democracy from Robert A. Dahl and and Jack Snyder to see the challenge of the democratization in the Arab states, in this case the states which are mentioned by the writer as the central theme of this research, those are Tunisia, Egypt, and Syria. 


\section{Democracy}

Democracy has been discussed for about two thousand and five hundred years old, it is long enough to give a frame of clear idea about democracy which can be agreed by all people, or almost all people in the world (Dahl,2001: 3). Traditionally, the democratic states are characterized, one of them, by applying openly political system of multiparty and the regime change is done by having general election for free, the economics of free market, and the freedom of the press is guaranteed. In contrary, the non-democratic states are characterized of having central power from the elite of one political party, the economic system isn't opened, the media (press) is controlled by the government. However, by following the time, democracy is not just understood as political freedom, but it also includes the justice concept and social similarities (Kompas, 23/04/2015).

Here, we can take the main point that actually democracy is a system giving chance for people in general to participate in order the running government can give priority for the universal good (people). Hence, the system must be transparent, accountable, and give chance for people for the public participation, mainly after the Arab Spring happened.

\section{Democracy from Robert A. Dahl}

Robert A. Dahl introduces the term "democratic foundation" to world of politics. From this democratic foundation, Dahl gives pre-requirement, by studying it from the populist theory, of the three democratic characteristic which can be meaningful for the application; (1) popular sovereignty, (2) political equality, and (3) majority rule (Krouse, 1982:442-443).

Dahl also tries to make classification of the democracy in two forms; those are substantive democracy and procedural democracy or "poliarchy" (Dahl's term). The substantive democracy is the democracy bringing principle and values of the democracy in the practice level. Meanwhile, the procedural democracy focuses more on the freedom of the society to choose. Dahl also adds the important of the foreign actors in the democratization in a state. 


\section{Democracy from Jack Snyder}

Besides using the theory of democracy according to Robert A. Dahl in this research, the writer also uses theory of democracy according to Jack Snyder where the democracy according to Snyder has two important stages. Snyder differentiates that the term of the democratization consists of mature democracies and democratizing states.

First stage, from Snyder, is the democracy he names mature democracies; the democracy getting the stable stage. In the mature democracy, government policy, including foreign policy and military policy, is arranged by the elite (leader) through the fair and justice general election and also subsequent; elite's actions are limited by some constitutional regulations and the obligation toward the civil freedom. Meanwhile, the second stage is the democratizing states. Snyder gives definition of this second stage as the state which has just implemented one or some requirement of the democracy, mentioned above; even though, the state remains having the important characteristic of the non-democratic system (Snyder, 2003:16-17).

\section{Democracy from George Sorensen}

George Sorensen says that the transition from non democratic to democratic rule is a complex process involving several phases, although ascertaining where one phase begins and another ends is difficult. Sorensen introduces to us the transition toward democracy which can be seen in Figure 1.1.

Figure 1. 1. Transition of Democracy

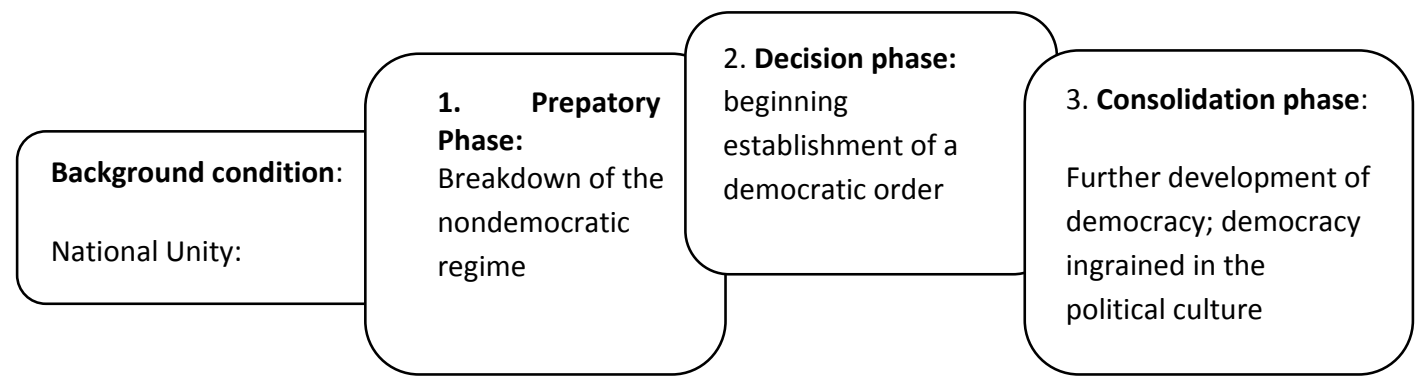

Those theories of democracy from Dahl, Snyder, and Sorensen that writer uses in this research to see the democratization in the Arab world having some challenges and why Syria has different phase from Tunisia and Egypt. 


\section{Outline}

In the previous, it is mentioned that the Arab Spring began from Tunisia when a youth 26 years named Mohammed Bouazizi protested against repressive regimes by setting himself on fire. This incident also stirred up the courage of the people of Tunisia widely to fight the regime Zein Al-Abidin Ben Ali (next Ben Ali) by conducting demonstrations against the regime in the streets. The power of the people allied to resist Ben Ali regime couldn't be longer capable of dammed by force officials belonging to the regime. Ben Ali was finally decided to leave the country which he had led with authoritarianism way.

Egypt includes one of the countries which was inspired and exposed domino effect regime from the collapse of Ben Ali in Tunisia. As we know that there was joint event persecution against children young man named Kollena Khaled Sa'eed in June 2010, less than six months before the same event happened the persecution of Bouazizi, in Tunisia (Korany, 2014: 270). However, torture case of Khaled Sa'eed did not succeed to build the power of the people in resisting the arbitrary regime in Egypt.

People power movement arose in Egypt after seeing that the people who united against regime in Tunisia succeeded in overthrowing Ben Ali. Hence, a few days after the world knew the end of Ben Ali power, Egyptian people came down to the streets demanding the resignation of president Hosni Mubarak judged authoritarian, corrupt, and failed to develop the state for 30 years of his powers. In addition, the demonstrator demanded reform of government (Jamshidi, 2014: 9).

Repressive treatment of Bouazizi and Khaled Sa'eed from the apparatus in Egypt confirmed what was said by Maryam Jamshidi that in Arab countries in general regime treated its people by not respecting the rights of humanity. Regime, including its officials, treats of the people in accordance with his (arbitrary) (Jamshidi, 2014: 28). In detail about the repressive treatment shows in table 1 . The evidence of the authoritarianism of the three Arab countries (Tunisia, Egypt, and Syria) is shown from the above table where Tunisia, Egypt, and Syria are in the category of countries which are not free (Not Free /NF). It is also confirmed the results of research that most of the Arab countries still authoritarian or anti-democracy. This is the 
beginning of the change in Arab countries. Marc Lynch wrote that if Arab regimes refused to change, they would be change from below (Foreign Policy: 41).

Table 1. Political Rights and Rank of Civil Liberties for the Countries of An Offer (Middle East \& North Africa)

\begin{tabular}{c|c|c|c} 
Country & Political rights & Civil Liberties & Status \\
\hline Israel & 1 & 2 & $\mathrm{~F}$ \\
\hline Jordania & 4 & 4 & $\mathrm{PF}$ \\
\hline Bahrain & 5 & 5 & $\mathrm{PF}$ \\
\hline Djibouti & 5 & 5 & $\mathrm{PF}$ \\
\hline Kuwait & 5 & 4 & $\mathrm{PF}$ \\
\hline Lebanon & 5 & 4 & $\mathrm{PF}$ \\
\hline Maroko & 5 & 4 & $\mathrm{PF}$ \\
\hline West Bank dan Gaza & 5 & 6 & $\mathrm{NF}$ \\
\hline Yaman & 5 & 5 & $\mathrm{PF}$ \\
\hline Algeria & 6 & 5 & $\mathrm{NF}$ \\
\hline Mesir & 6 & 5 & $\mathrm{NF}$ \\
\hline Iran & 6 & 6 & $\mathrm{NF}$ \\
\hline Irak & 6 & 6 & $\mathrm{NF}$ \\
\hline Oman & 6 & 5 & $\mathrm{NF}$ \\
\hline Qatar & 6 & 5 & $\mathrm{NF}$ \\
\hline UAE & 6 & 5 & $\mathrm{NF}$ \\
\hline Libya & 7 & 7 & $\mathrm{NF}$ \\
\hline Saudi Arabia & 7 & 6 & $\mathrm{NF}$ \\
\hline Suriah & 7 & 6 & $\mathrm{NF}$ \\
\hline Tunisia & 7 & 5 & $\mathrm{NF}$
\end{tabular}

Note: rating 1 (figures show the results of the best, the number 7 show the results of the worst. F represent "free" PF is partly free (a little free), and NF is not free. (Source: www.Freedomhouse.org $/$ template.cfm?page $=351 \&$ anapage $=341$ \&year $=2008$ (Harrigan dan El-Said, 2011: 32).

\section{Fluctuating Factor of the Arab Spring}

From this research's result appears that the three countries (Tunisia, Egypt, and Syria) have some similarity of condition of social economic and political influencing the fluctuation of the Arab spring. First, the three countries are led authoritarian leaders having power for long years and the leaders who seize power without the process of democratic elections. Second, three countries built political system with one party; in Tunisia Ben Ali overwhelm political stage with Rassemblement Constitutionnel Democratique (RCD), in Egypt, Mubarak ruled with 
Hizbul Wathan (HW) party, in Syria, Al-Assad dominates the politics by Ba'ath party. Third, these countries have a record of violation of the human rights and limit the expression of the people including absence of press freedom. Fourth, economic crisis and the increasing the level of unemployment are faced by the people of the three countries.

Hussein A. Hassouna also noted that the majority of Arab countries are developing countries which the level of illiteracy is very high (Hassouna: 50-51). In 2009, data showed that the level of illiteracy in Tunisia reached 22.3 percent, Egypt reached 33.6 percent, and Syria was about 16.9 percent (Ottaway 2010: 52). In general, the level of unemployment among young people in countries showing reached $23.5 \%$, including the highest unemployment rate in the world (Jamshidi, 2014: 7). Because of the factors above, mass movement which was held in Arab countries have the same characteristics, namely protesting against the condition of social and economic, rejecting the dictatorship, and fighting against corruption (Ramadan: 7). In other words, it can be concluded that there were many problems ahead of the Arab the spring. There are at least four major problem that trigger fluctuations; poverty, unemployment or limited employment, the increase of the price of basic foodstuffs, as well as corruption, collusion, and nepotism. The countries of the volatile, generally, like natural resources, but his people poor and democracy clogged (Kompas, 4/03/ 2011).

In addition, the fluctuation the Arab Spring of 2011 and also there was not irrespective from the revival or the emergence of intellectual communities in Arab countries. In Tunisia, there had been opposition group existing for years moving to support and build public awareness, namely Moadda. In Egypt, there was also Kefaya Movement promoting a demonstration in 2004 and 2005 that conveyed people aspiration and its support for Palestinian struggle (Marcovitz: 23). Meanwhile, in Syria, it appeared the movement called "Damascus Spring" in the beginning of Bashar al-Assad's administration. "Damascus spring" was the renewal of a movement that all were given a place by Bashar al-Assad, but it was sudden in an instant barred and "Damascus spring" bacame "Damascus Winter" (Ghadbian, 2001: 636). 
The media, beside the intellectual role, had great role in the Arab Springin 2011. It was because the media played a key role so some observers called it with "internet revolutions" (Ramadan:45). The mass media had function effectively and massively in delivering the protest of the people against the regime of Ben Ali in Tunisia to all Arab countries, even the world. Several years before the Arab Spring, Ahmed El Godi had said that the resurrection of the internet had shaken the Arab world. Democracy based on the internet has grown. The Arab world regimes tried to tighten control on access of the internet (El Godi, 2007: 223).

However, Russell E. Lucas sees that while the youth and social media have played an important part of the Arab Spring, it is impossible to understand the latter event without taking account of the economic and political contexts of the Arab world (Lucas, 2014: 326). The media, Jacqueline S. Ishmael and Shereen T. Ishmael, just a tool that serves spreading disappointment and dissatisfaction in public on the situation of political economy faced by the people of Arab widely (Ishmael, 2014: 230).

\section{The problem of political legitimacy of the Arab countries}

It has been explained from the earlier pages that the Arab Spring gave hope of the Arab world for the better life, through democratic political order. However, Arab countries still have problems in the political legitimacy. It is important to look at Michael Hudson's thesis saying that the main problem of the Arab countries, including Tunisia, Egypt and Syria, is on the low legitimacy of the politics. Hudson sees that the low legitimacy of politics caused by leadership in the Arab states built based on the traditional authority. Leadership based on the traditional authority, Hudson said, is based on the patriarchal authority.

The second is consultative tradition. This pattern leadership is a leadership building authority based on blind and absolute obedience at the sight of the aspect of tribes. Long before Hudson wrote that book, the theory of "Ashabiah" from Ibn Khaldun had already been very popular to read characteristic of the leadership of Arab states, namely loyalty to a tribe (Ashabiah).

Third factor is religion (Islam). Hudson sees that Islam, whose doctrine that absolute power to the only God has leverage large enough crisis over the 
legitimacy of political in political culture of the Arabic countries. Last (four), the feudal leadership. Feudal leadership is where possession of property (wealth), social control and power rests in the hands of a group of elite proprietor of lands. The elite landlords have big contribution of the growing up legitimacy of the authority elite (Hudson 1977: 84-98).

Legitimacy crisis of the politics in the Arab States caused the people in general were not given chance to participate directly in taking policy or decision. In Tunisia, Zein al-Abidin Ben Ali (Ben Ali) was appointed as president after the peaceful overthrowing of Bourguiba through coup d'état on 7 November 1987, one month after Bourguiba appointed him as Prime Minister (PM) of Tunisia.In Egypt, Hosni Mubarak became president after President Anwar Sadat, appointing him as vice president, was killed during a military parade on 6 October 1981 (Kompas, $5 / 02 / 2011)$.

It is different in Syria; Assad became president because his father, Hafez al-Assad opened a shortcut for him to reach the top of Syrian political leadership. In the end, a day after Hafez al-Assad died on 10 June 2000, namely on the date of 11 June, Ba'ath party, the ruling party, nominated Bashar al-Assad as presidential candidate. There was no other candidate besides Bashar al-Assad. Al-Assad was formally appointed as president of Syria after the implementation of a referendum on 10 July 2000, in which the result of the referendum was 92,29 percent supporting Bashar al-Assad to become president of a substitute for his father (Kuncahyono, 2012: 58-60).

Here, it is clear that the political process passed by the three leaders to reach a political leadership in each of their countries didn't have a strong political legitimacy. They became supreme leader not through the result of the democratic elections where we know that by process of involving public participation of democracy (broadly), the political legitimacy could be achieved. It is read by Hudson because the Arab world didn't have ability to adequate political participation of the society to build political support needed for regimes which wavers (Hudson 1978: 161-162). 


\section{Foreign intervention in fluctuation the Arab spring}

The Arab Spring also makes the Arab countries as the arena of the race for the influence of the big countries. The existence of the foreign sectors in the Arab spring was not in spite of their respective national interests that saw that the Middle East, more specifically the Arab world, has a charm or charm. Fascination or charm of the Arab world would be discussed following.

The involvement of foreign sectors in the political turbulence legitimated by the international law called humanitarian intervention. Of this law, the foreign sectors have jurisdictional reason to involve and interfere. This humanitarian intervention is classified by O'Brien into some the requirements, (i) there should be a threat of human rights, especially the massive violation of the human right; (ii) the intervention should be curtailed only for protection upon the humanity; (iii) action is not based an invitation from the local government; and (iv) the action is not done on the basis of Security Council resolution (Thontowi, Iskandar, 2006: 260).

Tracking the involvement of foreign sectors in the political dynamics in the Middle East, particularly Arab countries, we can make a mapping of involvement in three forms, namely in the form of assistance (cooperation), pressure, and the role of social media in influencing public opinion and policy direction although these foreign involvements with a different way. For the example USA didn't involve much of the political transition in Tunisia. Foreign sectors involve more in political transition in Tunisia is the European Union, especially France. On the contrary, USA is active in keeping its political interests in Egypt to escort the process of political transition. USA hopes that Egyptian leader after Hosni Mubarak is a leader who can cooperate and continue maintaining its national interests, including to maintain and protect the existence of Israel.

The case is different in Syria. USA does political consolidation massively to topple the regime of Bashar al-Assad including by building news in social media discrediting Assad. Whereas China (Tiongkok), Russia and Iran take different political position from United States of America (USA). The three countries unite to give political support for Assad. That is one of the reasons why Assad could not be overthrown by the opposition getting support from the USA and its ally. The 
involvement of the foreign sectors is felt dominantly in political transition in Arab states after the Arab Spring, 2011.

\section{Political Reform In The Arab States}

Democracy becomes the non-separated part of The Arab Spring. The Arab Spring, by the fall of the authoritarian leaders, became the beginning of the hope of the people in The Arab States to live with the democratic system. So, focus of the discussion from the world leaders and scholars is the initiatives and efforts to build the democratically political system. Even though we know that the will and initiatives for the democratic life didn't just begin from the Arab Spring of early 2011 last.

Halim Barakat in his book with the title The Arab World: Society, Culture, and State (2012) also said that since the beginning of 1990s, the Arab people actually had had expectation of the democratic life. This is made stronger by the survey result released by Arab Human Development Report (AHDR) in 2003 showed that 60 percent of the Arab people supported democracy and 80 percent of them rejecting authoritarian regime (Sau, 2004: 4233).

This expectation is followed by the initiatives for the political reform of the Arab world toward the more democratic life. The initiatives are following: 1) The League of Arab States created the Committee on Human Rights in 1968, and it adopted a human rights charter in 1994 (Hassouna, 2001: 51). 2) From the conference lasting in Barcelona in 1995, it was agreed to make a media becoming the center of the relationship between Europe and Mediterranean states (Middle East), EuroMed relations. The name of the media was Euro-Mediterranean Partnership (EMP) where in the Euro-Mediterranean Association Agreements systematically put human right and democracy as essential element of the agreement (WouterdanDuquet, 2013: 232-236). 3) In December 2002, United States of America launched a program named Middle East Partnership Initiative (MEPI). It was a program to support the political and economical reform, also the empowerment of the women. Bush in his administration made democratization in the Middle East as one of his concern (Ottawaydan Carothers, 2004: 23). 4) As the United States was hosting the G8 summit in 2004, it sought to broaden support for its political reform 
initiative for the region by soliciting the support of the other G8 countries (Muasher, 2008: 236). 5) The $44^{\text {th }}$ President of the United States, Barack Obama, when he was in England on $25^{\text {th }}$ May 2011, he made press conference promising that he would make discussion with the G8 countries related to the support which they could give of the reform movement and democratization lasting in the Middle East (Kompas, 26/05/2011).

Those initiatives were taken for the political reform needed by the Arab states to build the ethic of the good government. Just by that way, according to Tariq Ramadhan, civil society and democracy can be in real life in the Arab states (Ramadan: 143). The political event of 2011 opens chance more to build democratically political order in the Arab states, including in Tunisia, Egypt, and Syria. As a consequence, Nader Hashemi said that the Arab Spring is the important and historic political event in relation to political transformation in the Arab states. According to Hashemi, The Arab Spring enables to be called "Fourth wave of Democratization"(Hashemi, 2013: 207). Hillary Rodham Clinton, when she was still the Foreign Minister of USA, gave political statement about the Arab Spring by saying that this is for the first time in some decades of the Arab people to get the chance for the change, the chance where people voice and aspiration can be heard (Clinton, 2011: 468). That is the democracy dreamed by Arab society.

However, the Arab states must begin it by building political order which can be the foundation of the democracy. It is also said by Jack Snyder that it is needed the strong democratically political institutions as the previous one of the democratic transition to prevent the elite to exploit exclusionary nationalism to spread instability and conflict (Hwang: 6). At this aspect, democratization has some challenges in the Arab states, including Tunisia, Egypt, and Syria becoming the study in this research. According to John L. Esposito, the most important challenge for Islamic reformers will be the transfer of their reformulations from the elite few to the institutions and peoples of Islam (Esposito, 2004: 100). The aothor tries to map the challenges of the democratization in the Arab states as following: 


\section{Culture and Sociology of the Arab Society as the Hindrance Factor of the Democratization.}

Religious (Islam) factor, understanding, and tradition also the faithful based on tribe implementing patriarchal political culture and neo-patriarchal become the characteristic of the Arab politic right now. This is explored by Hisyam Syarabi that patriarchal is the "universal form of the traditional society" of the Arab which is contrast to modernity "beginning in the West Europe." Basic assumption from Syarabi's research is that the renaissance process of the Arab is just to deform not to change patriarchal structure of the Arab society. In the other words, modernization supplies itself as the basic of the society and hybrid culture. Neo-patriarchal which is not traditional and not modern can't perform itself as the integrated social and political system. One of the central fixture is "father figure (patriarch) is dominant, as the center where around it the nation and family are organized. So, between the ruling and ruled, between the father and his children, just there is vertical relation; in those two forms, the will from the paternal figure is the absolute one which in the society and family is mediated by the consensus based on ritual and coerce" (Barakat: 202-20).

\section{West Intervention as Obstacle of Democratization}

Another factor becomes an obstacle of the democratization in the Arab states, besides cultural and sociological factors, is the existence of the foreign actors taking initiatives and also sometimes to make fail the result of the democratic process. Attitude and perspective of the Islamic people are also paradox. In another side, they hate the West, even try to destroy it, and many of them uses sadism way to reach their target. The West is not just accused to take initiatives of destroying the Islamic world systematically and it is planned in the big scale, but also to do penetrated conspiracy to the small details of the Muslim state. Historic factor of this Islam-West relationship, in my opinion, has important influence of the democratization process in the Arab states, even after the turbulence of the Arab Spring.

Above all, it has been explored that the initiatives of the democratization in the Arab states, either before or after the turbulence of the Arab Spring, are 
mostly taken by the West states, mainly the United States of America. In this aspect, the problem comes because the initiatives are suspected to have the hidden agenda. It is seen when the Arabic newspaper based in London (England), Al-Hayat, published the leak of USA documents known as Greater Middle East Initiative (GMEI) on February $19^{\text {th }}$ of 2004 , some elements of the Arab world, generally the intellectuals/scholars, responded with full of suspect ion.

This makes the initiatives of the democratization coming from the West, mainly the US, always find challenge, mainly from the fundamental group. The democratization initiated actively by US is pure for making better the life of the Arab people, but the most important thing is the national interest of US itself. This argument goes stronger by Sidik Jatmika, the International Relations Lecturer of Muhammadiyah University of Yogyakarta. Jatmika says that USA plays the double standard in the Middle East, including the Arab World. USA supports democratization in some states, but in another side USA supports, even enjoying the relationship with the authoritarian regimes/states, such as Saudi Arabia, the nearest state to USA (Jatmika, 2000: 69).

Many facts also show that the foreign states, mainly USA which is in another side is active to take democratization initiatives in the Arab states, but in another side its existence always tries to make fail the democratization lasting in some Arab states. Politic of double standard played by US because democracy is the "project" foreign policy/politic of USA. USA will be active to support the democratization if it will not threaten its national interest. In contrary, USA will enjoy having cooperation with the authoritarian regimes if it can keep its national interest and keep its influence in the Middle East.

Politic of double standard played by USA because USA and the West states, in general, worry about the increase of the Islamic politic (their term, "Islamic Tyranny") after the Arab Spring event and the growth of the democratization. This is said by Ellis Goldberg that West has been in a worry where the crises will make the democratization come to fast in Egypt, for example, which will give chance for the political increase of Muslim Brotherhood (Goldberg, 2011: 111). 


\section{Conclusion}

The Arab Spring has opened the hope for the democratization in the Arab States which had been ruled by the authoritarian regimes for a long time. The Arab Spring became the momentum of the uprising of the people power to fight against the tyrannical regimes; such as Ben Ali in Tunisia, Mubarak in Egypt, and Assad in Syria, even though Assad still keeps its power until today in the middle of the attack from the opposition having support from the West.

As a result, after the Arab Spring turbulence of 2011, the Arab States are moving to build the democratically political systems, even though effort of having democratic system has many challenges, either it comes from the internal (people and the government of the Arab States itself) or from the external. The internal challenge is the culture and sociology of the Arab people where the people were not given political participation in large and also the low participation from the women. The Arab states are categorized as the states where the political participation of the women is very low, until today.

In this case, the author sees that history of the Muslim states has influence of the low political participation where we know that after the era of Khulafa al-Rasyidun ended, the spirit of democracy (musyawarab) built by Muhammad SAW ended and political position began by dynasty (family). This political dynasty was lasting until the end of the glory of the Turkey Usmani era (1924). Besides that, the scariness from the ruling regimes to lose their powers also becomes the obstacle of the democratization because they were proved to kill the intellectual community (civil society) which can support democratization. Ben Ali did it in Tunisia, so did Mubarak by eradicating the critically intellectual communities, such as Kefaya Movement. Bashar al-Assad, in Syria, also did it even though he gave support for the intellectual groups in the beginning of his administration. Whereas, the external challenge is the coming of the foreign states, mainly the United States of America playing double standard politic. The United States of America (USA) will overthrow the leader elected democratically if he can't keep its political interest. So, the foreign sector will be actively to take the initiative for democratization, but in another side the foreign sector is proved to make the democratization failed.

The foreign sectors, mainly USA, worry to lose their political influence in 
the Middle East if it has result of the democratic leaders which are not pro to the West. Besides, USA and its ally worry about the awakening of the Islamic political movement which can threaten its political interest in that region. It is seen from the role played by the USA in Egypt case where USA participated in overthrowing Mursi because Mursi was viewed to threaten USA's ally. It is far different from the case of Tunisia. This state succeeds in consolidating its democratization because USA does not come there to intervene. Tunisia has closed ally to the European Union, mainly France, which doesn't play double standard politic in the democratization in the Arab state of North Africa.

Figure 2. The Democratization in Arab States

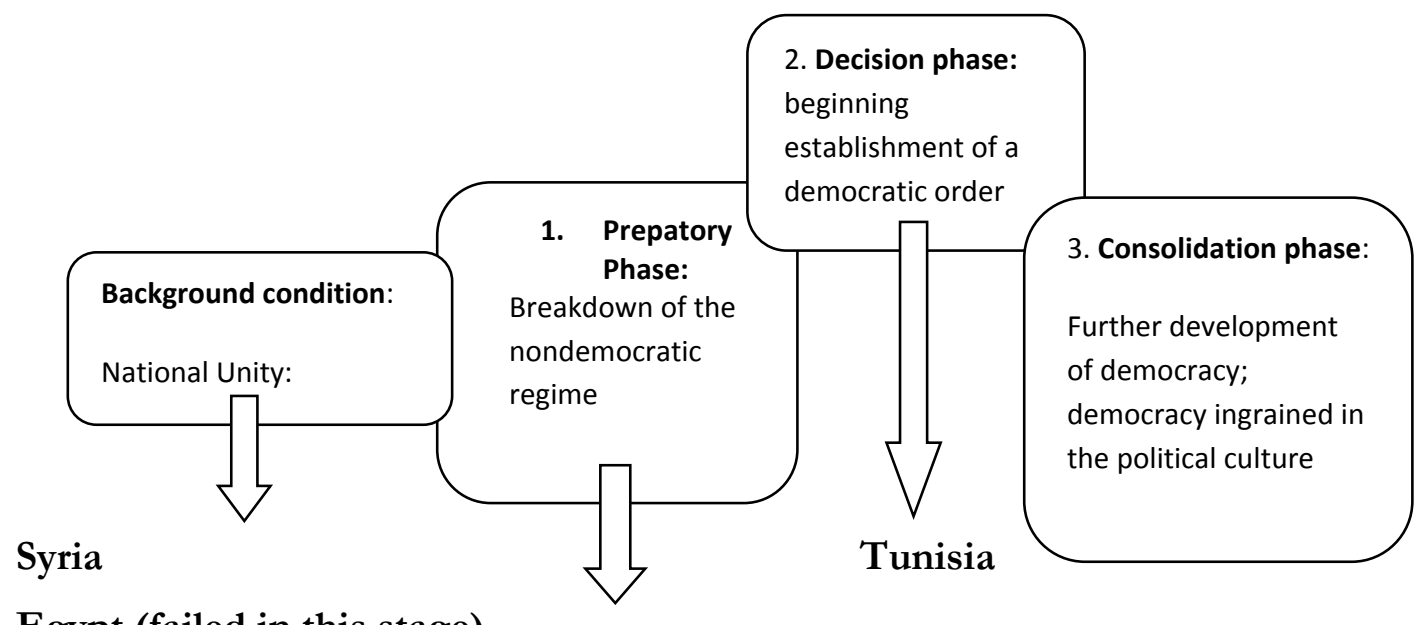

Egypt (failed in this stage)

In reading the democratization in the Arab states by using Georg Sorensen's theory, the three states, based on Figure 2, have been in the different phases. Even though, Georg Sorensen's theory, if it's viewed from the phases, is almost same with Jack Snyder's theory in substantial. Tunisia has been in the far step of its democratization (in the second phase), followed by Egypt (first phase), and Syria hasn't given much progress or positive step. In Syria, the national unity has not been obtained to overthrow Bashar al-Assad's authoritarian regime.

Tunisia's position in the second phase (based on Sorensen's theory) has been in the mature democracy, based on Jack Snyder's theory, whereas Egypt and Syria are still in the stage of democratizing state, even Egypt democracy failed in the first phase after the people power movement succeeded in overthrowing 
authoritarian regime and the people succeeded in having general election in the middle of 2012.

\section{References}

\section{Book}

Barakat, Halim. (2012). Dunia Arab, Masyarakat, Budaya, dan Negara. Bandung: Nusa Media.

Burdah, Ibnu. (2014). Islam Kontemporer, Revolusi dan Demokrasi. Malang: Intrans Publishing.

Clinton, Hillary Rodham. (2011). Hillary Rodham Clinton's Remarks at the Gala Dinner Celebrating the U.S.-Islamic World Forum. Dalam The New Arab Revolt, What Happened, What It Means, and What Comes Next. New York: Council on Foreign Relation.

Dahl, Robert. (1971). Polyarchy: Participation and Opposition. New Heaven, Con: Yale University Press.

El Godi, Ahmed. (2007). New Media, New Audience, New Topics, and New Forms of Censorchip in The Middle East. Dalam New Media and the New Middle East. New York: Palgrave Macmillan.

Esposito, John L. (1996). Ancaman Islam, Mitos Atau Realitas? Terj. Alwiyah Abdurrahman dan MISSI. Bandung: Mizan.

Goldberg, Ellis. (2011). Mubarakism Without Mubarak. Dalam The New Arab Revolt, What Happened, What It Means, and What Comes Next. New York: Council on Foreign Relation.

Hudson, Michael C. (1977). Arab Politics, The Search For Legitimacy. New Haven and London: Yale University Press.

Hwang, Julie Chernov. (2011). Umat Bergeak, Mobilisasi Damai Kaum Islamis di Indonesia, Malaysia, dan Turki. Terj. Samsudin Berlian. Jakarta: Freedom Institute.

Jamshidi, Maryam. (2014). The Future of Arab Spring. Civic Entrepreneurship in Politics, Art, and Technology Startups. USA: Elsevier Inc.

Jatmika, Sidik. (2000). AS Penghambat Demokrasi. Membongkar Politik Standar Ganda Amerika Serikat. Yogyakarta: Bigraf Publishing. 
Kuncahyono, Trias. 2012. Musim Semi di Suriah. Jakarta: Kompas.

Lucas, Russell E. (2014). The Persian Gulf Monarchies and The Arab Spring. Dalam buku Beyond The Arab Spring, The Evolving Ruling Bargain in The Middle East edited by Mehran Kamrava. New York: Oxford University Press.

Marcovitz, Hal. (2014). The Arab Spring Uprisings. United States: Reference Point Press

Muasher, Marwan. (2008). The Arab Center. The Promise of Moderation. London: Yale University Press.

Ramadan, Tariq. (2012). Islam and the Arab Awakening. New York: Oxford University Press.

Snyder, Jack. (2003). Dari Pemungutan Suara ke Pertumpahan Darah. Terj. Martin Aleida dan Parakitri T. Simbolon. Jakarta: Kepustakaan Populer Gramedia.

Sorensen, Georg. (2008). Democracy and Democratization, Processes and Prospects in a Changing World. Denmark: Westview Press.

Thontowi, Jawahir dan Pranoto Iskandar. (2006). Hukum Internasional Kontemporer. Bandung: Refika Aditama.

\section{Journal}

Ghadbian, Najib. (2001). The New Asad: Dynamics of Continuity and Change in Syria. Source: Middle East Journal, Vol. 55, No. 4 (Autumn, 2001), pp. 624641. Published by: Middle East Institute.

Hassouna, Hessein A. Arab Democracy: The Hope. Source: World Policy Journal, Vol. 18, No. 3 (Fall, 2001), pp. 49-52. Published by: The MIT Press and the World Policy Institute.

Ismael, Jacqueline S. dan Shereen T. Ismael. (2013). The Arab Spring and the Uncivil State. Vol. 35, No. 3, Special Issue: Perspectives on the Arab. Uprisings (Summer 2013), pp. 229-240. Published by: Pluto Journals. Source: Arab Studies Quarterly, Vol. 35, No. 3, Special.

Krous, Richard W. 1982. Polyarchy \& Participation: The Changing Democratic Theory of Robert Dabl. Source: Polity, Vol. 14, no. 3 (Spring, 1982), pp. 441-463. 
Ottaway, David B. 2010. The Arab Tomorrow. Source: The Wilson Quarterly (1976-), Vol. 34, No. 1 (WINTER 2010), pp. 48-64. Published by: Wilson Quarterly.

Sau, Ranjit. Democracy and Reform: Voices in West Asia. Sumber: Economic and Political Weekly, Vol. 39, No. 38 (Sep. 18-24, 2004), pp. 4232-4234.

Wouters, Jan dan Sanderijn Duquet. The Arab Uprisings and the European Union: In Search of a Comprehensive Strategy. Sumber: Yearbook of European Law, Vol 32, No. 1 (2013), pp, 230-265.

\section{Website}

Sadiki, Larbi. (2014). “Tunisia's democratisation taking off”. Aljazeera. News 17 Mei 2014. (accessed on 22 February 2017). Retrieved from http://www.aljazeera.com/indepth/opinion/2014/05/tunisiaconstitution-democracy-2014516161024354720.html

\section{Printed Newspaper}

Kompas. (2011). “AS dan Inggris Bahas Krisis Dunia Arab”. Edisi 26 Mei 2011.

Kompas. (2011). “AS Susun Proyek Timur Tengah Baru”. Edisi 4 Maret 2011.

Kompas. (2011). “Masa Depan Mesir Tak Pasti”. Edisi 5 Februari 2011.

Kompas. (2015). “60 Tahun KAA, Demokrasikah Solusinya?”. Edisi 23 April 2015. 